\title{
The Toarcian Oceanic Anoxic Event and the Jenkyns Event (IGCP-655 final report)
}

\author{
${ }^{1}$ Departamento de Geología, Universidad Jaén, Campus Las Lagunillas sn, 23071 Jaén, Spain; *Corresponding author, E-mail: mreolid@ujaen.es \\ ${ }^{2}$ Université de Lyon, UCBL, ENSL, CNRS, LGL-TPE, Villeurbanne 69622, France \\ ${ }^{3}$ Institut Universitaire de France, Paris, France \\ ${ }^{4}$ MARE and Departamento de Ciências da Terra, Polo II Edif Central, Universidade Coimbra 3000-272 Coimbra, Portugal \\ ${ }^{5}$ Department of Earth and Universe Sciences, University of Tlemcen, P.O. Box 119, Tlemcen, Algeria
}

(Received: February 5, 2020; Revised accept: February 29, 2020)

https://doi.org/10.18814/epiiugs/2020/020051

\section{Introduction}

A better understanding the functioning of Earth System in the context of past climatic upheavals is essential for predictions about the fate of the diversity of life and the future of our society. The International Geoscience Program (IGCP), a joint initiative of UNESCO and IUGS, serves as a knowledge hub to facilitate international scientific cooperation in the geosciences. One of the strategical themes of the IGCP is Global Change: evidence from the geological record, which perfectly applies to the project IGCP-655, Toarcian Oceanic Anoxic Event: Impact on marine carbon cycle and ecosystems.

The study of oceanic anoxic events that affected past marine ecosystems provides us the chance to create models which can be applied to ongoing environmental global changes and to understand future evolution of habitats and ecosystems. The Toarcian Oceanic Anoxic Event (T-OAE, Early Jurassic) is a good past analogue for ongoing climatic changes. This event occurred during the early Toarcian (Serpentinum Zone), around $182 \mathrm{Ma}$ ago, due to the Pliensbachian-Toarcian boundary is dated as $182.70 .7 \mathrm{Ma}$ in the International Chronostratigraphic Chart v.2020/01 (Cohen et al., 2013 updated). However, the U-Pb geochronology of Sell et al. (2014) indicated that Pliensbachian-Toarcian boundary is older than $183.5 \mathrm{Ma}$ and the beginning of the T-OAE was dated at 183.1 Ma. The term Toarcian Oceanic Anoxic Event was used initially by Farrimond et al. (1989). The T-OAE was an abrupt paleoenvironmental perturbation affecting the diversity of marine ecosystems (e.g., Jenkyns, 1988; Jenkyns and Clayton, 1997; Hesselbo et al., 2007). The end of the Pliensbachian sea-level regression was followed by a transgression which occurred during the Early Toarcian (Hallam et al., 1987; De Graciansky et al., 1998; Pittet et al., 2014; Haq, 2018) coeval with a widespread deposition of black shales in the majority of epicontinental basins (Jenkyns, 1988), and a global warming (Suan et al., 2011; García Joral et al., 2011; Korte and Hesselbo, 2011; Them et al., 2017a). A perturbation of the carbon cycle indicated by a negative carbon isotopic excursion (CIE) has been documented (Fig. 1) in both marine and terrestrial material (e.g., Jenkyns and Clayton, 1986; Schouten et al., 2000; Hesselbo et al., 2007; Al-Suwaidi et al., 2010; Suan et al., 2010; Caruthers et al., 2011; Izumi et al., 2012; Reolid,
2014; Rodrigues et al., 2019; Ruebsam et al., 2019, 2020a).

This Early Jurassic biotic crisis constitutes a second-order mass extinction for benthic organisms (Little and Benton, 1995; Aberhan and Fürsich, 2000; Cecca and Macchioni, 2004; Wignall et al., 2005; Gómez and Goy, 2011; Danise et al., 2013, 2019; Caruthers et al., 2014; Rita et al., 2016). This biotic crisis was probably driven by oxygendepletion affecting platforms and oceanic deep environments (Röhl et al., 2001; Bucefalo Palliani et al., 2002; Wignall et al., 2005; Hermoso et al., 2009; Caruthers et al., 2014; Them et al., 2018; Reolid et al., 2012, 2019a).

The IGCP-655 project of the IUGS-UNESCO has constituted an international network of researchers with different disciplinary skills who collaborate and share conceptual advances. The IGCP-655 includes 111 researchers from 65 research centres corresponding to 26 countries. As a result, the IGCP-655 and the workshops organized provided a friendly platform for participants to communicate their own research results and to merge international experts, and research facilities to solve a truly global-scale problem. This project has favoured a multidisciplinary, integrated analysis of the T-OAE from stratigraphic successions outcropping in different regions all over the world combining biotic (microfossils, macroinvertebrates and vertebrate assemblages) and abiotic data (sedimentology, cyclostratigraphy, mineralogy, elemental geochemistry, and isotopic geochemistry).

Our project aims at investigating the climatic changes related to the sea-level rise, carbon cycle perturbation, global warming and secondorder mass extinction through detailed studies of Upper Pliensbachian to Middle Toarcian biostratigraphy, ichnology, paleoecology, ecostratigraphy, sedimentology, mineralogy, geochemistry, biogeochemistry and cyclostratigraphy. Our project attempts at documenting the collapse of global marine ecosystems and their subsequent recovery. One of the main challenges is the knowledge of the mechanisms related to the biotic response of various organisms at different trophic levels, from different habitats and climate zones (calcareous nannofossils, radiolarians, foraminifera, ostracods, dinoflagellates, bivalves, brachiopods, ammonites, and vertebrates) to climate and environmental adverse conditions. Finally, the IGCP-655 also focused on the understanding of the feedbacks between carbon cycle perturbation and global warming and the impact on marine ecosystems and primary productivity. 


\section{Classic and Promising new Pliensbachian-Toar- cian Stratigraphic Sections}

The recent and future advances in the knowledge of the T-OAE are derived from the collaborative fieldwork in reference to Pliensbachian to Toarcian successions. It includes the Peniche section (Lusitanian Basin, Portugal; Fig. 1), the Lower Toarcian GSSP (Rocha et al., 2016) where studies are continuously developing (e.g., Baker et al., 2017; Correia et al., 2017a; Duarte et al., 2017; Fantasia et al., 2019a; Ferreira et al., 2019; McArthur et al., 2019; Rita et al., 2019). Other classic sections such as Valdorbia (Umbria Marche Basin, Italy), María Pares (Lusitanian Basin), Yorkshire (Cleveland Basin, UK; Fig. 2) and Sancerre (Paris Basin) have been the subject of study during the IGCP-655 project, for analyses on foraminifera (Reolid et al., 2019b), palynostratigraphy (Correia et al., 2017a; Slater et al., 2019), benthic macroinvertebrates (Caswell and Dawn, 2019), sedimentology (Kemp et al., 2018), geochemistry (Dickson et al., 2017; Thibault et al., 2018; Reolid et al., 2019b) and cyclostratigraphy (Boulila and Hinnov, 2017; Saker-Clark et al., 2019).

Other classic material for the research on the T-OAE is the Mochras core (Cardigan Bay Basin, Wales; Fig. 1), where continuous research on magnetostratigraphy (Xu et al., 2018a), organic and inorganic geochemistry (Xu et al., 2018b), foraminiferal assemblages (Reolid et al., 2019a) and cyclostratigraphy based on $\delta^{13} \mathrm{C}_{\text {TOC }}$ (Storm et al., 2020) have been recently published. Additional cores in the Lombardian Basin (Northern Italy), Colle di Sogno and Gajum cores, can be considered reference material for the pelagic lower Toarcian of the western Tethys and will provide high resolution data (Erba et al., 2019).

During the last three years, other promising sections for the Upper Pliensbachian-Lower Toarcian have been studied in Swiszerland (Riniken and Gipf sections from Jura and Creux de l'Ours section from Sub-Briançónais Basin; Fantasia et al., 2019b), in the South Iberian Paleomargin (La Cerradura section; Reolid et al., 2019c; Rodrigues et al., 2019; Ruebsam et al., 2020a; Fig. 1), in the North Gondwana paleomargin in Morocco (Issouka, Amellago and Talghemt sections; Bodin et al., 2016; Ait-Itto et al., 2017, 2018; Boulila et al., 2019; Rodrigues et al., 2020) and in Algeria (Raknet El Kahla section; Ruebsam et al., 2020b).

In Asia, marine deposits from Tibet (Bilong Co section, Chen et al., 2017; Fu et al., 2017) and cores of lacustrine deposits from Sichuan Basin (Xu et al., 2017) have been analysed confirming the incidence of the carbon cycle perturbation in basins out of marine environments. Moreover, sections from Western Panthalassa paleomargin show both negative CIE and oxygen-depleted conditions, such as in the Toyora area from Japan (Sakuraguchi-dani section; Izumi et al., 2018a, b; Kemp et al., 2019; Fig. 1). In the other side of the Panthalassa, more sections have expanded the knowledge of the T-OAE away from Tethyan paleomargins. Among others, we can indicate the East Tributary Bighorn Creek section (Fig. 1) and Haida Gwaii section in North America
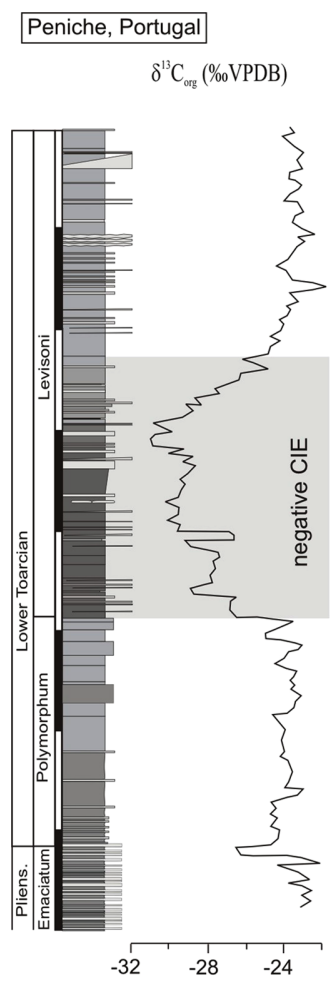

Fantasia et al. (2019a)
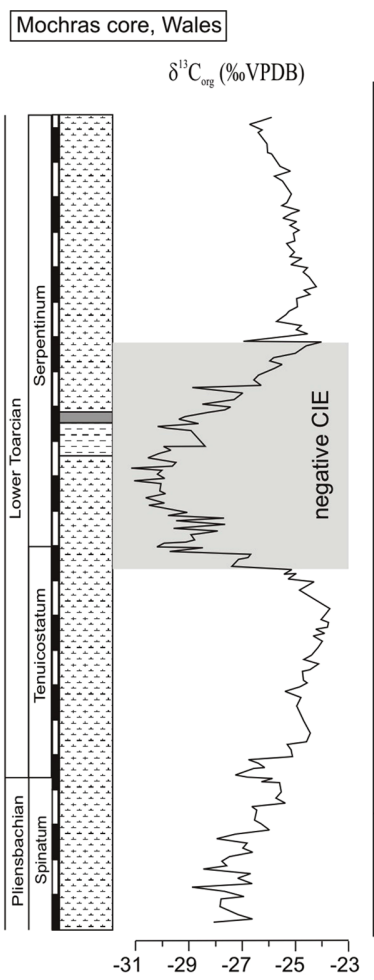

Xu et al. $(2018 b)$

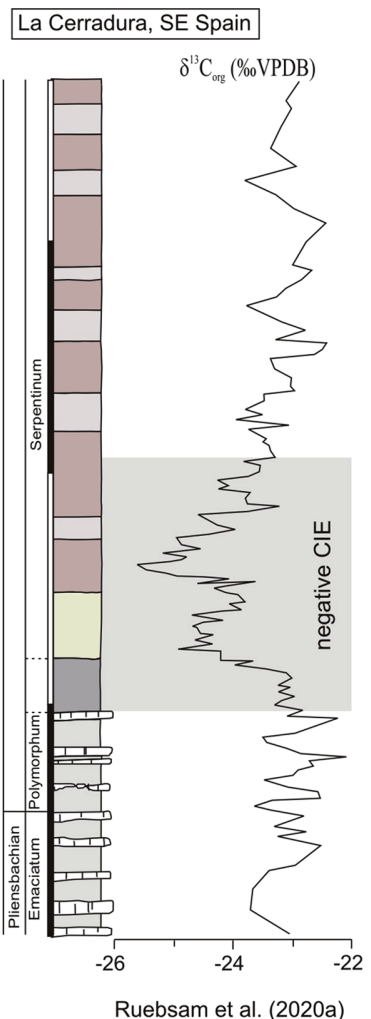

Ruebsam et al. (2020a)

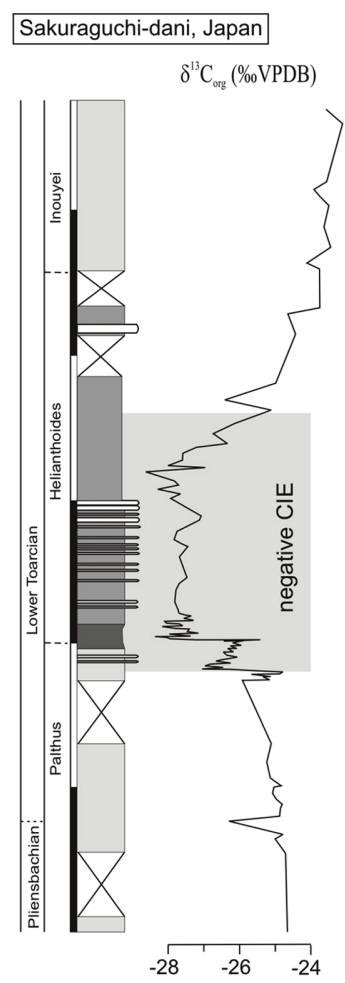

Kemp and Izumi (2014) Izumi et al. (2018b)

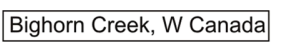
$\delta^{13} \mathrm{C}_{\text {org }}(\% \mathrm{VPDB})$

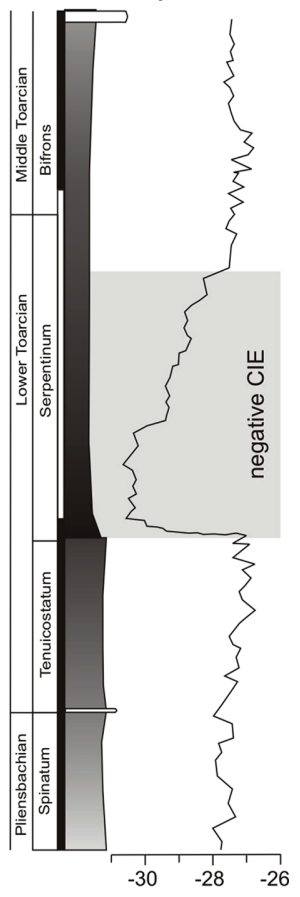

Them et al. (2019)

Figure 1. Recent works showing the negative CIE obtained from $\delta^{13} C_{\text {org }}$ values in different parts of the world: Peniche section from Lusitanian Basin, Mochras Core from Cardigan Bay Basin, La Cerradura section from South Iberian Palaeomargin, Sakuraguchi-dani section from Toyora area in the west Panthalassa, and East Distributary of Bighorn Creek section from east Panthalassa. The light-grey shaded area corresponding to the negative CIE has been located in the different sections between the level of sharp decrease of $\delta^{13} C_{\text {org }}$ values and the return to pre-excursion values. 
Eastern Panthalassa paleomargin (Western Canada; Caruthers et al., 2011; Them et al., 2017b) and Arroyo Lapa section from Neuquen Basin (Argentina; Al-Suwaidi et al., 2016; Ros-Franch et al., 2019).

\section{Main Advances of the IGCP-655 on the T-OAE}

The T-OAE is documented as one of the most significant global events of the Mesozoic, but still there is no general consensus about the causes: volcanic $\mathrm{CO}_{2}$ and thermogenic $\mathrm{CH}_{4}$ related to the emplacement of the Karoo-Ferrar Large Igneous Province (McElwain et al., 2005; Hesselbo et al., 2007; Fantasia et al., 2019a); b) destabilization of marine methane hydrates (Hesselbo et al., 2000; Kemp et al., 2005); c) increased rates of wetland methanogenesis (Them et al., 2017b) and deterioration of climate-sensitive reservoir permafrost areas during global warming (Ruebsam et al., 2019, 2020a).

Several environmental changes have been involved in the mass extinction event in the marine ecosystems, such as marine deoxygenation, ocean acidification, rapid greenhouse warming event, and incidence of sea-level changes (e.g., Hallam, 1987; McArthur et al., 2000; Bailey et al., 2003; Jenkyns, 2003; Gómez and Goy, 2011; Trecalli et al., 2012; Rita et al., 2016; Caswell and Frid, 2017; Them et al., 2018). Numerous studies point to a significant geographical variability of this event and to the effect of regional-scale processes influencing marine (McArthur et al., 2008; Rodríguez-Tovar and Uchman, 2010; Reolid et al., 2014, 2018; Han et al., 2018; McArthur, 2019) and terrestrial environments (e.g., Rodrigues et al., 2016; Baker et al., 2017).

The contributions of the members of the IGCP-655 during the three years of activity (2017-2019), have improved our understanding of the T-OAE. Most of these advances were presented in the three annual meetings of the project, the International Workshop on the T-OAE in Jaén, Spain (2017), Coimbra, Portugal (2018) and Erlangen, Germany (2019). The major advances are summarized in three main research topics:

\section{Stratigraphy and Sedimentology}

The analysis of stratigraphic successions of the Pliensbachian-Toarcian is an important tool for interpreting environmental conditions and eustatic changes and constitutes the framework for subsequent analyses of paleontological and geochemical data. Some studies have documented the frequency of tempestite deposits during the Early Toarcian in areas such as the South Iberian Paleomargin (Molina and Nieto, 2019), the Tibetan Carbonate Platform (Han et al., 2018) and the Andean Basin in northern Chile (Fantasia et al., 2018). The increase of storm deposits during the Early Toarcian highlight the close link between global warming and tropical cyclones (Krencker et al., 2015). Many works have focused on the interpretation from the geological record of the interaction of the oceanographic changes, climatic changes and carbonate productivity (e.g., Baroni et al., 2018; Han et al., 2018; Izumi et al. 2018a; Suan et al., 2018). Some studies put special attention on the analysis of sea-level fluctuations in the context of the sequence stratigraphy. Krencker et al. (2019) interpreted that a forced regression preceded the transgression related to the T-OAE. Fantasia et al. (2019a, 2019b) studied stratigraphic fluctuations of $\delta^{13} \mathrm{C}$, TOC and sedimentary features for interpreting sea-level changes and paleoceanographic incidence.

Cyclostratigraphic studies have been applied to Iberian Range (Val et al., 2017), Middle Atlas and High Atlas of Morocco (Martinez et al., 2017; Ait-Itto et al., 2018) and Wales (Xu et al., 2018a) with special emphasis on the orbital chronology. Ait-Itto et al. (2018), Them et al. (2018), Xu et al. (2018b) and Fantasia et al. (2019a) studied the incidence of volcanism on the paleoenvironmental change. Ruebsam et al. (2019) proposed that the cryosphere demise in high latitude was related to the global warming and the glacioeustatic sea-level change. Reolid et al. (2019c) focused in the analyses of carbon and sulfur isotopes from celestine concretions in the Lower Toarcian of South Iberian Paleomargin for interpreting the potential development of cold seeps during the lattermost Pliensbachian and early Toarcian.

\section{Effect of the T-OAE on Marine Communities}

Most of the works on fossil assemblages have focused on the analysis of benthic forms. The analysis of the diversity and composition of foraminiferal assemblages is a valuable tool for interpreting paleoenvironmental conditions during the Toarcian biotic crisis. The analysis of foraminiferal morphogroups has been employed with very good results on the SE France (Jozsa et al., 2018), the Lusitanian (Maria Pares section, Reolid et al., 2019b) and the Cardigan Bay Basin (Mochras core; Reolid et al., 2019a), for characterizing the different phases of the biotic crisis and the recovery of the foraminiferal assemblages. These works have evidenced the incidence of the oxygen-depleted conditions, the role of opportunist forms and the subsequent recovery of the diversity after the biotic crisis. Salazar-Ramírez et al. (2019) have shown a stepwise extinction of benthic foraminifera in the Basque-Cantabrian Basin (Spain) during the Early Toarcian and faunal turnover in the Serpentinum Zone.

The other microfossil group intensely studied is ostracoda. Soulimane et al. (2017a, b) analyzed the turnover of ostracod assemblages at the Pliensbachian-Toarcian transition and at the T-OAE in different paleomargins from the Southwestern Tethys. Finally, Soulimane et al. (2020) propose a distribution of ostracod bioprovinces and the changes during the beginning of the Toarcian in the western Tethys.

The analysis of calcareous nannofossils, and the relationship with carbonate productivity and paleoceanography during the T-OAE, has been studied by Ferreira et al. (2017). The analysis of calcareous nannofossils has allowed the refinement of biostratigraphy as well as a better knowledge of diversity fluctuations during the Pliensbachian and Toarcian (Ferreira et al., 2019; Menini et al., 2019). Based on the Lusitanian Basin record, Correia et al. (2017a, 2017b) studied the response of dinoflagellates to the T-OAE.

Relevant advances have been obtained concerning to the incidence of the T-OAE on macroinvertebrate communities, mainly brachiopods (e.g., Baeza-Carratalá et al., 2017, 2018; García Joral et al. 2018; Danise et al., 2019; Piazza et al., 2019), bivalves (Posenato et al., 2018; Brame et al., 2019; Damborenea and Pagani, 2019; Ros-Franch et al., 2019), and cephalopods (Rita et al., 2018). Many works have focused on the analysis of diversity and changes in the body-size trends of organisms at the Early Toarcian extinction event as well as in the recovery stage (García Joral et al., 2018; Rita et al., 2018, 2019; Caswell and Dawn, 2019; Danise et al., 2019; Piazza et al., 2019; Ros-Franch et al., 2019). Most of these papers show a decrease of body-size as a precursor of 
the biotic crisis, and the recovery after stressing conditions disappear. The decrease in size was also recorded for calcareous nannofossils (Ferreira et al., 2017).

Ichnological analyses have been useful for interpreting changes in the sedimentation, oxygenation and nutrient availability in the substrate. Therefore, Rodríguez-Tovar et al. $(2017,2019)$ show good examples from the Lusitanian Basin with paleobiological changes of tracemakers and opportunistic behavior as a response to the T-OAE. Reolid and Reolid (2020) have analysed the geochemical distribution pattern from spotted marl-limestone successions in the La Cerradura section.

The study of fossil vertebrates was conducted on especially wellpreserved specimens and facies from Canada, Germany and England (e.g., Konwert and Stumpf, 2017; Martindale et al., 2017; Vincent et al., 2017; Muscente et al., 2019). The main studied groups were actinopterygians (Konwert and Stumpf, 2017; Maxwell and Martindale, 2017; Maxwell and Stumpf, 2017; Johnson et al., 2019), elasmobranchs (Stumpf and Kriwet, 2019), ichthyosaurs (Plet et al., 2017), plesiosaurs (Vincent et al., 2017) and teleosauroids (Johnson et al., 2019).

The Early Toarcian global warming affected also terrestrial ecosystems. Rodrigues et al. (2019) proposed a decreased ${ }^{13} \mathrm{C}$ fractionation during photosynthesis in $\mathrm{C} 3$ plants and arid environments from the Iberian Paleomargin. Slater et al. (2019) showed that the fossil spore-pollen assemblages from Pliensbachian-Toarcian indicated that vegetation shifted from a high-diversity assemblage with conifers, seed ferns and lycophytes, to a low-diversity assemblage of cheirolepid conifers, cycads and Cerebropollenites-producers adapted to warm drought-like conditions.

\section{Geochemistry, Environmental Conditions and Paleocli- matology}

Various types of geochemical proxies are gradually leading to a better understanding of the environmental factors controlling the climate, the oceanographic circulation, the weathering intensity, and the role of volcanism.

Stable isotopes geochemistry was based mainly on $\delta^{13} \mathrm{C}$ and $\delta^{18} \mathrm{O}$, but also on $\delta^{34} \mathrm{~S}$ and $\delta^{15} \mathrm{~N}$. Most of the analyses have been performed on bulk rock sample (e.g., Bougeault et al., 2017; Them et al., 2017a), belemnite rostra (e.g., Ait-Itto et al., 2017; Arabas et al., 2017; Rosales et al., 2018), brachiopod shells (Ferreira et al., 2017; Baghli et al., 2020), and organic matter (e.g., Silva et al., 2017; Izumi et al., 2018a; Suan et al., 2018; Thibault et al., 2018; Rodrigues et al., 2019; Ruebsam et al., 2019, 2020a). Also $\delta^{98 / 95}$ Mo has been analysed from Central and North European sections for interpreting the incidence of euxinic conditions and water renewal during the T-OAE (Dickson et al., 2017). The osmium isotope $\left({ }^{187} \mathrm{Os} /{ }^{188} \mathrm{Os}\right)$ stratigraphy has been used to characterize the seawater composition and to approach the enhanced weathering during the T-OAE as a response to climatic warming (Them et al., 2017b). Them et al. (2019) studied the $\mathrm{Hg}$ content of sediments and detected an $\mathrm{Hg}$ anomaly during the T-OAE using many sections around the world and interpreting combined volcanic input and emerged land provenance.

The analysis of organic matter includes the determination of the total organic carbon (TOC), total sulfur, palynofacies and biomarkers. Some studies have focused on the paleoclimatic reconstruction from analysing the charcoal and phytoclast abundances and palynofacies (Baker et al., 2017; Xu et al., 2017; Fonseca et al., 2018; Suan et al., 2018;
Kemp et al., 2019; Rodrigues et al., 2019, 2020). These works also give information about the processes that happened in terrestrial environments, such as the incidence of wildfires on the $\mathrm{pO}_{2}$ (Baker et al., 2017). Finally, Ruebsam et al. (2020a) report the negative CIE from inorganic carbon, bulk organic carbon and fractions of molecular land plant fossils from Early Toarcian sediments that coincided with global warming and a carbon cycle perturbation. Based on differences in the magnitude of the CIE recorded in land plants and marine substrates Ruebsam et al. (2020a) infer that the Early Toarcian warming was paralleled by an increase in atmospheric $\mathrm{CO}_{2}$ levels from $\sim 500 \mathrm{ppmv}$ to $\sim 1000 \mathrm{ppmv}$.

Stable isotopes geochemistry $\left(\delta^{13} \mathrm{C}, \delta^{18} \mathrm{O}\right)$ has great potential for determining carbon cycle perturbations, paleotemperature, paleoceanographic changes and interpreting enhancement of the hydrological cycle (e.g., Izumi et al. 2018a, b; Rosales et al., 2018; Fantasia et al., 2019a). Redox-sensitive elements were used for interpreting oxygendepleted conditions (e.g., Izumi et al., 2018b; Reolid et al., 2019b; Thibault et al., 2018; Fantasia et al., 2018, 2019a) as well as the diameter of pyrite framboids (Izumi et al., 2018b; Suan et al., 2018). Some works have focused the interpretations in the potential development of euxinic conditions during the T-OAE (Ruebsam et al., 2018; Suan et al., 2018; Thibault et al., 2018).

\section{The Use of Terms T-OAE and Jenkyns Event}

Global effects of the Toarcian environmental perturbations have been recognized, since the 80 s, with the record of black shales as an evidence of seawater deoxygenation (e.g., Jenkyns and Clayton, 1986; Jenkyns, 1988). Later on, such sedimentary records have been associated with a prominent negative CIE, which interrupted a long-lasting positive excursion (Hesselbo et al., 2000; Xu et al., 2018b; Storm et al., 2020). If the black shale record is variable according to the paleogeographic context (Wignall et al., 2005; McArthur, 2019), the CIE seems to be a common feature of most of the studied sites (Fig. 1). There are other events in Earth history recording positive or negative, global CIE which are named after pioneer researchers, such as the Weissert Event (positive CIE of the mid Valanginian; Erba et al., 2004), Farahoni Event (positive CIE of the latest Hauterivian; e.g., Baudin and Riquier, 2014), Selli Event or Selli level (positive CIE of the early Aptian; e.g., Menegatti et al., 1998) and Bonarelli Event (positive CIE of the Cenomanian-Turonian boundary; Luciani and Cobianchi, 1999).

Müller et al. (2017) proposed to rename the T-OAE as the Jenkyns Event, in honour of the seminal contribution of Professor Hugh Jenkyns to the understanding of this event. Accordingly, we hereby propose to use "T-OAE" when studying marine deposits with evidence of oxygen-depleted conditions. The term "Jenkyns Event" has to be used for the global changes that occurred during the Early Toarcian. These include:

a) Carbon cycle perturbation evidenced by a prominent negative CIE affecting marine environments (e.g., Saelen et al., 1996; Reolid, 2014; Baghli et al., 2020) and land ecosystems (as evidenced in land plant organic matter, e.g., Hesselbo et al., 2007; Ruebsam et al., 2020a).

b) Oxygen-depleted conditions in marine ecosystems, in some areas with generalized anoxia and euxinia (e.g., Gill et al., 2011; Izumi et al., 2018a; Ruebsam et al., 2018; Suan et al., 2018), but not affecting all basins and paleomargins (e.g., Boomer et al., 2009; Reolid et al., 
Yorkshire coast - NW Europe
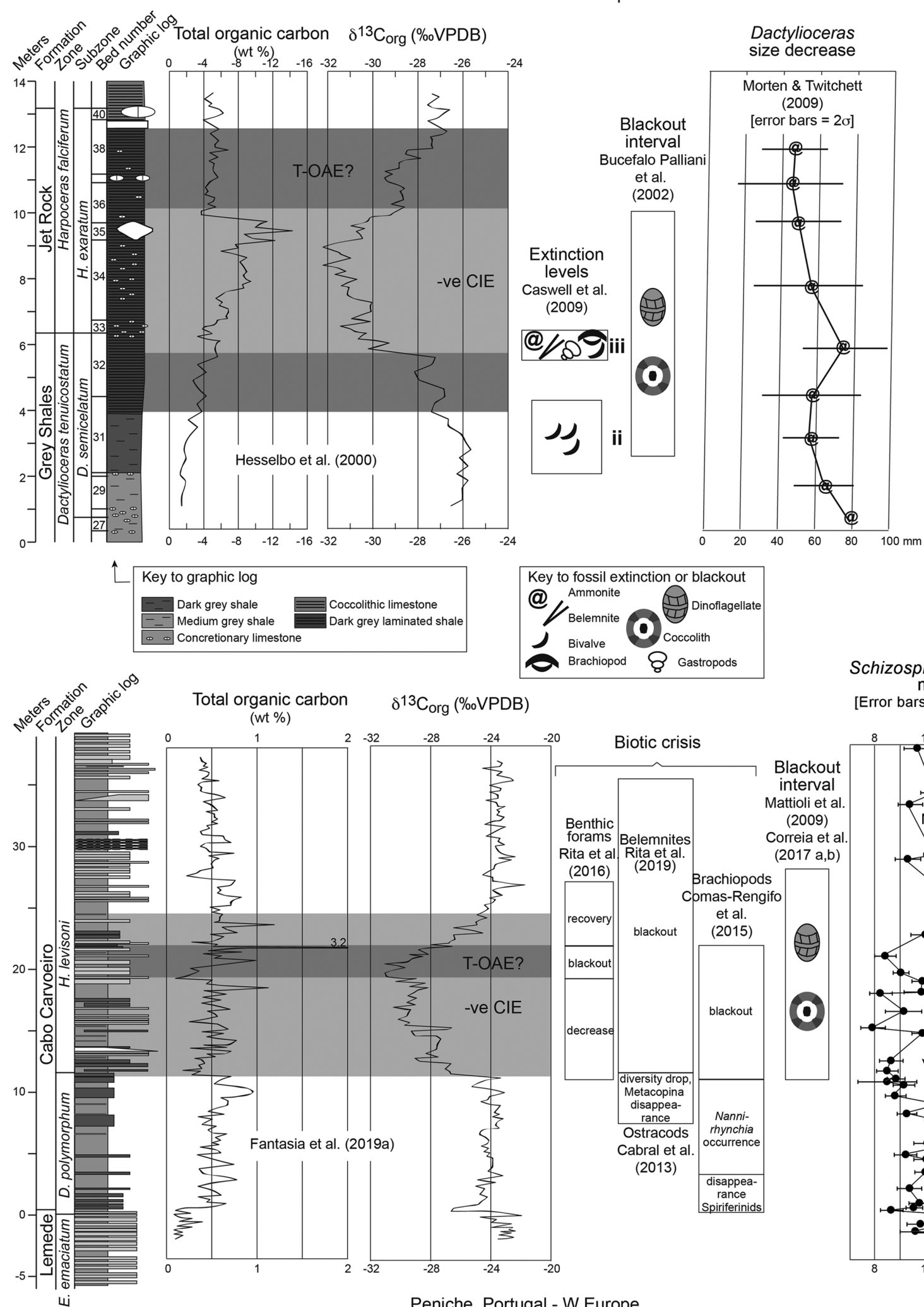

$\delta^{13} C_{\text {org }}(\% \circ V P D B)$

$-20 \quad$ Biotic crisis

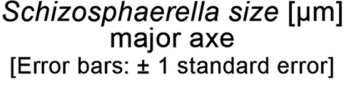

[Error bars: \pm 1 standard error]

$\begin{array}{llll}-32 & -28 & -24 & -20\end{array}$
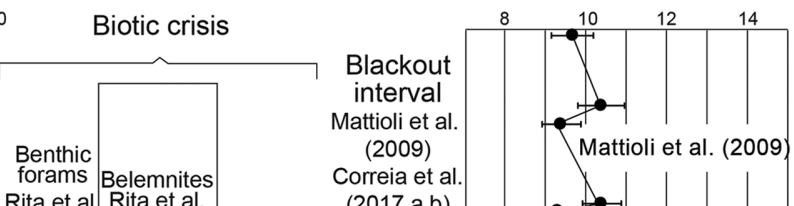

Rita et al. Rita et al.

(2016)

(2019)

Brachiopods

Correia et al.

recovery

Comas-Rengifo
et al.
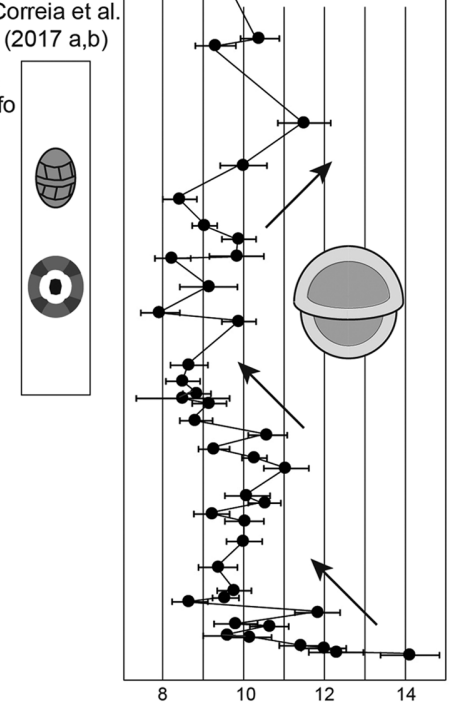

Figure 2. Synthesis of main environmental and biotic changes, namely extinctions, temporary disappearance and body-size decrease, occurring in two lower Toarcian iconic sections, namely the Yorkshire coast in NE England and the Peniche section in W Portugal. The ii and iii phases of biotic perturbations from Yorkshire section are described in Caswell et al. (2009). The dark-grey shaded intervals, corresponding to the local expression of the T-OAE, have been placed as following: (1) in the Yorkshire coast, wt\% TOC values steadily higher than 2\% and faunal extinction occurrence; (2) in the Peniche section, wt\% TOC peak, and belemnites and benthic fauna blackout. The light-grey shaded area corresponding to the negative CIE (the Jenkyns event) has been placed in both areas between the level of sharp decrease of $\delta^{13} C_{\text {org }}$ values and the return to pre-excursion values. 
2014, 2015; Miguez-Salas et al., 2017; McArthur, 2019).

c) Increase of TOC during the negative CIE, but to a variable extent depending on latitude and local environmental conditions (e.g., Wignall et al., 2005), with the most typical facies being black shales in central and north Europe (e.g., Jenkyns and Clayton, 1986; Bellanca et al., 1999; Röhl et al., 2001; McArthur, 2019).

d) Biotic crisis recorded with different incidence in marine ecosystems (e.g., Little and Benton, 1995; Caswell et al., 2009; Gómez and Goy, 2011; Danise et al., 2015; Caswell and Frid, 2017; Reolid et al., 2019a), but also recorded in terrestrial ecosystems with changes in diversity and composition in land plants (e.g., Mander and McElwain, 2019; Slater et al., 2019) and the increase of wildfires in some areas (Baker et al., 2017). The term crisis comprises: extinctions, decrease or temporary disappearance (blackout) of taxa, as well as reduction in body-size as observed for calcareous nannofossils (Mattioli et al., 2004a, b; Reolid et al., 2014; Clémence et al., 2015), micro- (benthic foraminifera; Rita et al., 2016) and macroinvertebrates (ammonites, Morten and Twitchett, 2009; belemnites, Rita et al., 2019; brachiopods, García Joral et al., 2018; Piazza et al., 2019). See Figure 2.

e) Climatic change including a global warming (e.g., Gómez et al., 2008; Korte and Hesselbo, 2011; Danise et al., 2013; Slater et al., 2019; Baghli et al., 2020), increasing weathering (e.g., Montero-Serrano et al., 2015; Fu et al., 2017), variations in detrital and nutrient input to marine basins (e.g., Rodríguez-Tovar and Reolid, 2013; Danise et al., 2015; Fantasia et al., 2019a; Kemp et al., 2019), and changes in marine productivity and a sea-level rise (e.g., Hallam, 1987; Röhl and SchmidRöhl, 2005; Wignall et al., 2005).

\section{IGCP-655 Activities}

The main activity of the IGCP-655 has been the three editions of the International Workshop on the Toarcian Oceanic Anoxic Event $(I W-T O A E)$. The $1^{\text {st }} I W-T O A E$ happened on October $4-7^{\text {th }} 2017$ in the University of Jaén (Spain) organized by the Prof. Matías Reolid. There were 38 scientific attendees, over 18 oral presentations, and 17 posters. The $1^{\text {st }}$ IW-TOAE meeting comprised four days of activities. The first day was dedicated to a short training course "The ichnological record as a tool to assess different order bio-events" by Prof. Francisco J. Rodríguez-Tovar and Dr. Javier Dorador of the University of Granada (Spain). Next day continued with the scientific sessions as well as an invited lecture by Prof. Stephen P. Hesselbo, (University of Exeter, UK) entitled "Changing perceptions of the Toarcian Oceanic Anoxic Event; past, present and future research questions and directions". In the last two days the participants visited the best Toarcian sections of the Subbetic (Betic Cordillera, SE Spain) such as the Fuente Vidriera section (Fig. 3a), the La Cerradura section, the Iznalloz section and the Arroyo Mingarrón section (see field guide, Reolid et al., 2018).

The $2^{\text {nd }}$ IW-TOAE took place in the University of Coimbra (Portugal) from 6 to $9^{\text {th }}$ of September, 2018, organized by the Prof. Luis V. Duarte, with the attendance of 47 researchers from 15 countries. There were 20 oral presentations and 15 posters with high-quality scientific contributions. The meeting comprised four days of activities. A first day for the scientific sessions began with the invited lecture by Prof. Hugh Jenkyns (University of Oxford, UK) titled "The Toarcian Oceanic Anoxic Event: lessons from the Cretaceous". The two following days were
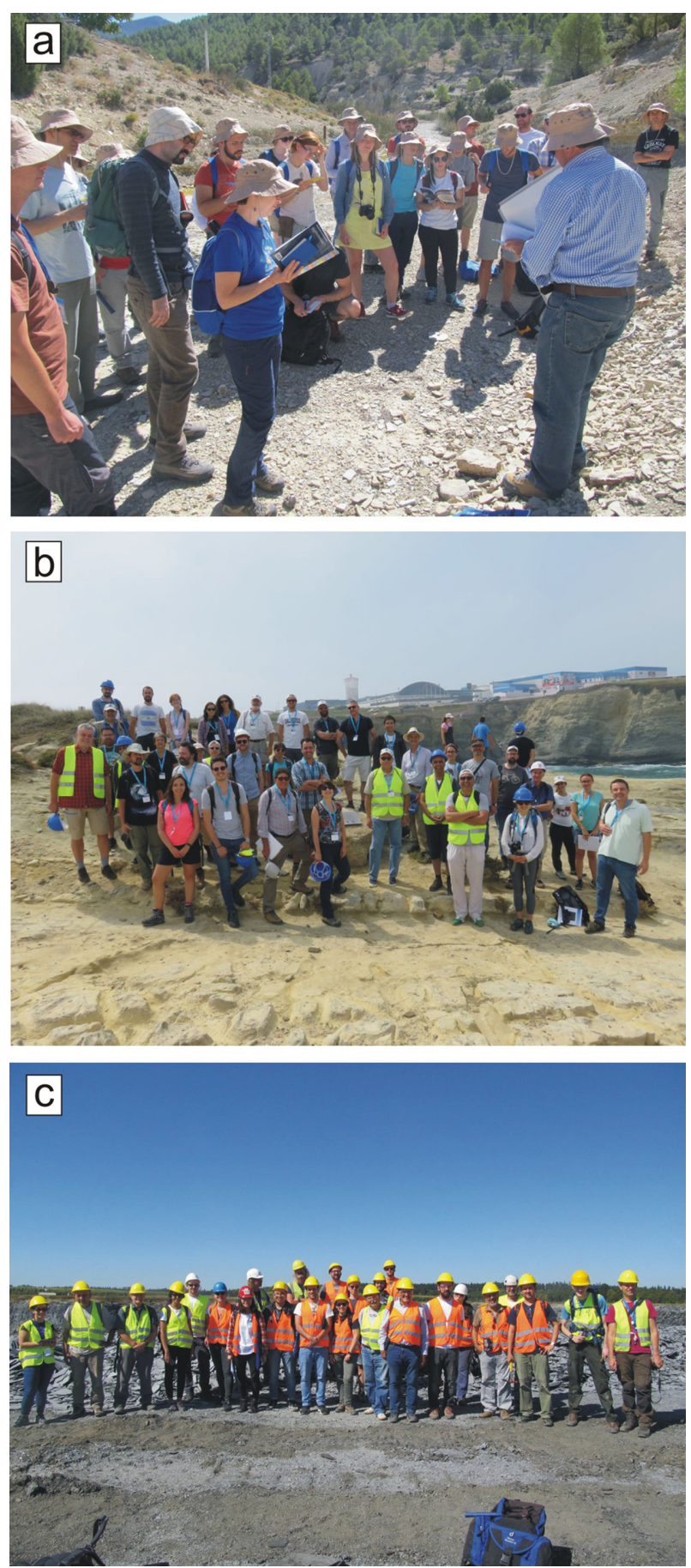

Figure 3. Researchers attending the different excursions to Pliensbachian-Toarcian sections during the three editions of the International Workshop on Toarcian Oceanic Anoxic Event (IW-TOAE). A. Visit to the Fuente Vidriera section in the Subbetic (Betic Cordillera, South Spain) during the $1^{\text {st }}$ IW-TOAE (October 2017). B. Visit to the Peniche section in the Lusitanian Basin (Portugal) during the $2^{\text {nd }}$ IW-TOAE (September 2018). C. Visit to the Dotterhausen Quarry (Swabian Alb, Germany) during the $3^{\text {rd }}$ IW-TOAE (September, 2019).

dedicated to the field trip visiting the classic Lower Jurassic sections of the Lusitanian Basin (see field guide, Duarte and Silva, 2018). Among the visited outcrops were Maria Pares (or Rabaçal) and Peniche sections (Fig. 3b), this latter considered the worldwide reference for the 
Pliensbachian-Toarcian transition (Toarcian GSSP). The last day of the meeting was dedicated to a short training course entitled "Organic matter characterization in anoxic marine facies: palynofacies and organic geochemistry approaches", coordinated by Prof. João Graciano Mendonça Filho from the Federal University of Rio de Janeiro (Brazil).

The $3^{\text {rd }}$ IW-TOAE was hosted by the Geozentrum Nordbayern of the Friedrich-Alexander University in Erlangen (Germany) between $2^{\text {nd }}$ and $5^{\text {th }}$ of September, 2019. This meeting began in the first day with three training courses: "3D imaging techniques, from CT-scanning acquisition to Drishti 3D-imaging software, and biometric analysis" taught by Christian Schulbert and Prof. Kenneth De Baets (Univ. Erlangen, Germany); "Biomolecules and molecular fossils" by Dr. Wolfgang Ruebsam (Univ. Kiel); and " $R$ short course on size/extinction/diversity patterns through time" thought by Prof. Dr. Manuel Steinbauer (Univ. Erlangen). The second day was focused on the scientific sessions including 24 oral and 14 poster communications with the invited lecture "The T-OAE: Marine ecosystem response across time and space" of Dr. Bryony Caswell (University of Hull, UK). The two following days were dedicated to the field trip focused on the T-OAE in the Swabian Alb and Franconian Alb, south Germany, with special focus on facies, geochemistry and fossil assemblages. Among the visited outcrops were the Dotternhausen Quarry of the Schwäbische Alb Geopark (Fig. 3c), the Buttentheim clay pit and the Teufelsgraben (see field guide, De Baets and Rita, 2019).

The scientific and social activities during the workshops gave many opportunities to explore new scientific networks and to share new ideas for advancing in the research on Mesozoic anoxic events. A number of early career scientists, $\mathrm{PhD}$ students and post-docs also attended the workshop. The educational function of the project is thus valuable.

\section{Acknowledgements}

This is a contribution of the IGCP-655 project of the IUGS-UNESCO. We would like to thank reviewer and editor for their careful review of the manuscript.

\section{References}

Aberhan, M., and Fürsich, F.T., 2000, Mass origination versus mass extinction: The biological contribution to the Pliensbachian - Toarcian extinction event. Journal of the Geological Society of London, v. 157, pp. 55-60.

Ait-Itto, F.Z., Price, G.D., Addi, A.A., Chafiki, D., and Mannani, I., 2017, Bulk-carbonate and belemnite carbon-isotope records across the Pliensbachian-Toarcian boundary on the northern margin of Gondwana (Issouka, Middle Atlas, Morocco). Palaeogeography, Palaeoclimatology, Palaeoecology, v. 466, pp. 128-136.

Ait-Itto, F.Z., Martinez, M., Price, G.D., and Ait-Addi, A., 2018, Synchronization of the astronomical time scales in the Early Toarcian: a link between anoxia, carbon-cycle perturbation, mass extinction and volcanism. Earth and Planetary Science Letters, v. 493, pp. 1-11.

Al-Suwaidi, A.H., Angelozzi, G.N., Baudin, F., Damborenea, S.E., Hesselbo, S.P., Jenkyns, H.C., Manceñido, M.O., and Riccardi, A.C., 2010, First record of the Early Toarcian Oceanic Anoxic Event from the Southern Hemisphere, Neuquén Basin, Argentina. Journal of the Geological Society of London, v. 167, pp. 1-4.

Al-Suwaidi, A.H., Hesselbo, S.P., Damborenea, S., manceñido, M.O., Jen- kyns, H.C., Riccardi, A.C., Angelozzi, G.N., and Baudin, F., 2016, The Toarcian Oceanic Anoxic Event (Early Jurassic) in the Neuquen Basin, Argentina: A reassessment of age and carbon isotope stratigraphy. Journal of Geology, v. 124, pp. 171-193.

Arabas, A., Schlögl, J., and Meister, C., 2017, Early Jurassic carbon and oxygen isotope reecords and seawater temperature variations: Insights from marine carbonate and belemnite rostra (Pieniny Klippen Belt, Carpathians). Palaeogeography, Palaeoclimatology, Palaeoecology, v. 485, pp. 119-135.

Baeza-Carratal, J.F., Reolid, M., and García Joral, F., 2017, New deepwater brachiopod resilient assemblage from the South-Iberian Palaeomargin (western Tethys) and its significance for the brachiopod adaptive strategies around the Early Toarcian Mass Extinction Event. Bulletin of Geosciences, v. 92, pp. 233-256.

Baeza-Carratal, J.F., Garcia Horal, F., Goy, A., and Tent-Manclus, J.E., 2018, Arab-Madagascan brachiopod dispersal along the North-Gondwana paleomargin towards the Western Tethys Ocean during the Early Toarcian (Jurassic). Palaeogeography, Palaeoclimatology, Palaeoecology, v. 490, pp. 252-268.

Baghli, H., Mattioli, E., Spangenberg, J.E., Bensalah, M., Arnaud-Godet, F., Pittet, B., and Suan, G., 2020, Early Jurassic climatic trends in the south-Tethyan margin. Gondwana Research, v. 77, pp. 67-81.

Bailey, T.R., Rosenthal, Y., McArthur, J.M., van de Schootbrugge, B., and Thirlwall, M.F., 2003, Paleoceanographic changes of the Late Pliensbachian-Early Toarcian interval: A possible link to the genesis of an oceanic anoxic event. Earth and Planetary Science Letters, v. 212, pp. 307-320.

Baker, S.J., Hesselbo, S.P., Lenton, T.M., Duarte, L.V., and Belcher, C.M., 2017, Charcoal evidence that rising atmospheric oxygen terminated Early Jurassic ocean anoxia. Nature Communications, v. 8, 15018. DOI: $10.1038 /$ ncomms 15018

Baroni, I.R., Pohl, A., van Helmond, N.A.G., Papadomanolaki, N.M., Coe, A.L., Cohen, A.S., van de Schootbrugge, B., Donnadieu, Y., and Slomp, C.P., 2018, Ocean circulation in the Toarcian (Early Jurassic): A key control on deoxygenation and carbon burial on the European Shelf. Paleoceanography and Paleoclimatology, v. 33, pp. 994-1012.

Baudin, F., and Riquier, L., 2014, The hauterivian Faraoni 'Oceanic Anoxic Event': an update. Bulletin de la Sociét Geologique de France, v. 185, pp. 359-377.

Bellanca, A., Masetti, D., Neri, R., and Venezia, F., 1999, Geochemical and sedimentological evidence of productivity cycles recorded in Toarcian black shales from the Belluno basin, southern Alps, northern Italy. Journal of Sedimentary Research, v. 69, pp. 466-476.

Bodin, S., Krencker, F.N., Kothe T., Hoffmann, R., Mattioli, E., Heimhofer, U., and Kabiri, L., 2016, Perturbation of the carbon cycle during the late Pliensbachian - early Toarcian: New insight from high-resolution carbon isotope records in Morocco. Journal of African Earth Sciences, v. 116, pp. 89-104.

Boomer, I., Lord, A.R., Page, K.N., Bown, P.R., Lowry, F.M.D., and Riding, J.B., 2009, The biostraigraphy of the Upper Pliensbachian-Toarcian (Lower Jurassic) sequence at Ilminster, Somerset. Journal of Micropalaeontology, v. 28, pp. 67-85.

Bougeault, C., Pellenard, P., Deconinck, J.F., Hesselbo, S.P., Dommergues, J.L., Bruneau, L., Cocquerez, T., Laffont, R., Huret, E., and Thibault, N., 2017, Climatic and palaeoceanographic changes during the Pliensbachian (Early Jurassic) inferred from clay mineralogy and stable isotope (C-O) geochemistry (NW Europe). Global and Planetary Change, v. 149, pp. 139-152.

Boulila, S., and Hinnov, L.A., 2017, A review and scale of the early Jurassic Toarcian OAE: implications for carbon cycle and sea level variations. Newsletters on Stratigraphy, v. 50, pp. 363-389.

Boulila, S., Galbrun, B., Sadki, D., Gardin, S., and Bartolini, A., 2019, Constraints on the duration of the early Toarcian T-OAE and evidence for carbon-reservoir change from the High Atlas (Morocco). Global and Planetary Change, v. 175, pp. 113-128. 
Brame, H.M.R., Martindale, R.C., Ettinger, N.P., Debeljak, I., Vasseur, R., Lathuiliere, B., Kabiri, L., and Bodin, S., 2019, Stratigraphic distribution and paleoecological significance of Early Jurassic (PliensbachianToarcian) lithiotid-coral reefal deposits from the Central High Atlas of Morocco. Palaeogeography, Palaeoclimatology, Palaeoecology, v. 514, pp. 813-837.

Bucefalo-Palliani, R., Mattioli, E., and Riding, J.B., 2002, The response of marine phytoplankton and sedimentary organic matter to the Early Toarcian (Lower Jurassic) oceanic anoxic event in northern England. Marine Micropaleontology, v. 46, pp. 223-245.

Cabral, M.C., Loureiro, I.M., Duarte, L.V., and Azerêdo, A.C., 2013, Registro da extinção dos Metacopina (Ostracoda, Crustacea) no Toarciano de Rabaçal, regio de Coimbra. Comunicaes Geológicas, v. 100, pp. 63-68.

Caruthers, A.H., Gröcke, D.R., and Smith, P.L., 2011, The significance of an Early Jurassic (Toarcian) carbon-isotope excursion in Haida Gwaii (Queen Charlotte Islands), British Columbia, Canada. Earth and Planetary Science Letters, v. 307, pp. 19-26.

Caruthers, A.H., Smith, P.L., and Gröcke, D.R., 2014, The PliensbachianToarcian (Early Jurassic) extinction: A North American perspective. Geological Society of America Special Paper, v. 505, doi:10.1130/ 2014.2505(11).

Caswell, B.A., and Dawn, S.J., 2019, Recovery of benthic communities following the Toarcian oceanic anoxic event in the Cleveland Basin, UK. Palaeogeography, Palaeoclimatology, Palaeoecology, v. 521, pp. 114-126.

Caswell, B.A., Coe, A.L., and Cohen, A.S., 2009, New range data for marine invertebrate species across the early Toarcian (Early Jurassic) mass extinction. Journal of the Geological Society, v. 166, pp. 859-872.

Caswell, B.A., and Frid, C.L.J., 2017, Marine ecosystem resilience during extreme deoxygenation: the Early Jurassic oceanic anoxic event. Oecologia, v. 183, pp. 275-290.

Chen, L., Xu, G.W., Da, X.J., Yi, H.S., Zhu, Z.X., Huang, Z.H., and Li, X.G., 2017, Chemo- and biostratigraphy of the Jurassic oil shales from the Qiangtang basin, Northern Tibet, China: A case study of the Toarcian Oceanic Anoxic Event. Acta geologica Sinica-English Edition, v. 91, pp. 630-643.

Cecca, F., and Macchioni, F., 2004, The two Early Toarcian (Early Jurassic) extinction events in ammonoids. Lethaia, v. 37, pp. 35-56.

Clémence, M.-E., Gardin, S., and Bartolini, A., 2015, New insights in the pattern and timing of the Early Jurassic calcareous nannofossil crisis. Palaeogeography, Palaeoclimatology, Palaeoecology, v. 427, pp. 100-108.

Cohen, K.M., Finney, S.C., Gibbard, P.L., and Fan, J.X., 2013 updated, The ICS International Chronostratigraphic Chart. Episodes, v. 36, pp. 199-204.

Comas-Rengifo, M.J., Duarte, L.V., Félix, F., García Joral, F., Goy, A., and Rocha, R.B., 2015, Latest Pliensbachian-Early Toarcian brachiopod assembalges from the Peniche section (Portugal) and its correlation. Episodes, v. 38, pp. 2-7.

Correia, V.F., Riding, J.B., Duarte, L.V., Fernandes, P., and Pereira, Z., 2017a, The palynological response to the Toarcian Oceanic Anoxic Event (Early Jurassic) at Peniche, Lusitanian Basin, western Portugal. Marine Micropaleontology, v. 137, pp. 46-63.

Correia, V.F., Riding, J.B., Fernandes, P., Duarte, L.V., and Pereira, Z., 2017b, The palynology of the lower and middle Toarcian (Lower Jurassic) in the northern Lusitanian Basin, western Portugal. Review of Palaeobotany and Palynology, v. 237, pp. 75-95.

Damborenea, S.E., and Pagani, M.A., 2019, Early Jurassic protobranch bivalves from Chubut, Argentina. Journal of Paleontology, v. 93, pp. 925-944.

Danise, S., Twichett, R.J., Little, C.T.S., and Clémence, M.E., 2013, The impact of global warming and anoxia on marine benthic community dynamics: an example from the Toarcian (Early Jurassic). PLoS ONE, v. 8, e56255.

Danise, S., Twitchett, R.J., and Little, C.T.S., 2015, Environmental controls on Jurassic marine ecosystems during global warming. Geology, v. 43 , pp. $263-266$.
Danise, S., Clémence, M.E., Price, G.D., Murphy, D.P., Gómez, J.J., and Twitchett, R.J., 2019, Stratigraphic and environmental control on marine benthic community change through the early Toarcian extinction event (Iberian Range, Spain). Palaeogeography, Palaeoclimatology, Palaeoecology, v. 524, pp. 183-200.

De Baets, K., and Rita, P. (eds.), 2019, III International Workshop and Fieldtrip of IGCP 655 Toarcian Oceanic Anoxic Event: Impact on marine carbon cycle and ecosystems. Fieldtrip guidebook. FriedrichAlexander Universitat Erlangen-Nüremberg, 24 pp.

De Graciansky, P.C., Jacquin, T., and Hesselbo, S.P., 1998, The Ligurian cycle: an overview of Lower Jurassic 2nd-order transgressive/regressive facies cycles in western Europe. SEPM Special Publication, v. 60, pp. 467-479.

Dickson, A.J., Gill, B.C., Ruhl, M., Jenkyns, H.C., Porcelli, D., Idiz, E., Lyons, T.W., and van den Boorn, S.H.J.M., 2017, Molybdenum-isotope chemostratigraphy and paleoceanography of the Toarcian Oceanic Anoxic Event (Early Jurassic). Paleoceanography, v. 32, pp. 813-829.

Duarte, L.V, Silva, R.L., Félix, F., Comas-Rengifo. M.J., Rocha, R.B., Mattioli, E., Paredes, R., Mendonça Filho, J. G. and Cabral, M.C., 2017, The Jurassic of the Peniche Peninsula (Portugal): scientific, educational and science popularization relevance. Revista Sociedad Geológica España, v. 30, pp. 55-70.

Duarte, L.V., and Silva, R.L. (eds), 2018, The Toarcian Oceanic Anoxic Event in the Western Iberian Margin and its context within the Lower Jurassic evolution of the Lusitanian Basin. Fieldtrip Guidebook, 2nd International Workshop on the Toarcian Oceanic Anoxic Event, Universidade de Coimbra, $102 \mathrm{pp}$.

Erba, E., Bartolini, A., and Larson, R.L., 2004, Valanginian Weissert oceanic anoxic event. Geology, v. 32, pp. 149-152.

Erba, E., Gambacorta, G., Visentin, S., Cavalheiro, L., Reolon, D., Faucher, G., and Pegorano, M., 2019, Coring the sedimentary expression of the early Toarcian Oceanic Anoxic Event: new stratigraphic records from the Tethys Ocean. Scientific Drilling, v. 26, pp. 17-27.

Fantasia, A., Föllmi, K.B., Adatte, T., Bernárdez, E., Spangenberg, J.E., and Mattioli, E., 2018, The Toarcian Oceanic Anoxic Event in southwestern Gondwana: an example from the Andean Basin, northern Chile. Journal of Geological Society, v. 175, pp. 883-902.

Fantasia, A., Thierry, A., Spangenberg, J.E., Font, E., Duarte, L.V., and Follmi, K.B., 2019a, Global versus local processes during the Pliensbachian-Toarcian transition at the Peniche GSSP, Portugal: A multi-proxy record. Earth-Science Reviews, v. 198, art. 102932. Doi:10.1016/j.earscirev.2019.102932.

Fantasia, A., Föllmi, K.B., Adatte, T., Spangenberg, J.E., and Mattioli, E., 2019b, Expression of the Toarcian Oceanic Anoxic Event: New insights from a Swiss transect. Sedimentology, v. 66, pp. 262-284.

Farrimond, P., Eglinton, G., Brassell, S.C., and Jenkyns, H.C., 1989. Toarcian anoxic event in Europe: An organic geochemical study. Marine and Petroleum Geology, v. 6, pp. 136-147.

Ferreira, J., Mattioli, E., Sucherás-Marx, B., Giraud, F., Duarte, L.V., Pittet, B., Suan, G., Hassler, A., and Spangenberg, J.E., 2019, Western Tethys Early and Middle Jurassic calcareous nannofossil biostratigraphy. Earth-Science Reviews, v. 197, art. 102908. Doi:10.1016/j.earscirev.2019.102908.

Ferreira, J., Mattioli, E., and van de Schootbrugge, B., 2017, Palaeoenvironmental vs. evolutionary control on size variation of coccoliths across the Lower-Middle Jurassic. Palaeogeography, Palaeoclimatology, Palaeoecology, v. 465, pp. 177-192.

Fonseca, C., Mendonça Filho, J.G., Lézin, C., Duarte, L.V., and Fauré, P., 2018, Organic facies variability during the Toarcian Oceanic Anoxic Event record of the Grands Causses and Quercy basins (southern France). International Journal of Coal Geology, v. 190, pp. 218-235.

Fu, X.G., Wang, M., Zeng, S.Q., Feng, X.L., Wang, D., and Song, C.Y., 2017, Continental weathering and palaeoclimatic changes through the onset of the Early Toarcian oceanic anoxic event in the Qiangtang Basin, Eastern Tethys. Palaeoceanography, Palaeoclimatology, Palaeoecology, v. 487 , pp. $241-250$. 
García Joral, F., Gómez, J.J., and Goy, A., 2011, Mass extinction and recovery of the Early Toarcian (Early Jurassic) brachiopods linked to climate change in northern and central Spain. Palaeogeography, Palaeoclimatology, Palaeoecology, v. 302, pp. 367-380.

García Joral, F., Baeza-Carratal, J.F., and Goy, A., 2018, Changes in brachiopod body size prior to the Early Toarcian (Jurassic) Mass Extinction. Palaeogeography, Palaeoclimatology, Palaeoecology, v. 506, pp. 242249.

Gill, B.C., Lyons, T.W., and Jenkyns, H.C., 2011, A global perturbation to the sulfur cycle during the Toarcian Oceanic Anoxic Event. Earth and Planetary Science Letters, v. 312, pp. 484-496.

Gómez, J.J., and Goy, A., 2011, Warming-driven mass extinction in the Early Toarcian (Early Jurassic) of northern and central Spain. Correlation with other time-equivalent European sections. Palaeogeography, Palaeoclimatology, Palaeoecology, v. 306, pp. 176-195.

Gómez, J.J., Goy, A., and Canales, M.L., 2008, Seawater temperature and carbon isotope variations in belemnites linked to mass extinction during the Toarcian (Early Jurassic) in central and Northern Spain. Comparison with other European sections. Palaeogeography, Palaeoclimatology, Palaeoecology, v. 258, pp. 28-58.

Hallam, A., 1987, Radiations and extinctions in relation to environmental change in the marine Lower Jurassic of northwest Europe. Paleobiology, v. 13, pp. 152-168.

Han, Z., Hu, X., Kemp, D.B., and Li, J., 2018, Carbonate-platform response to the Toarcian Oceanic Anoxic Event in the southern hemisphere: Implications for climatic change and biotic platform demise. Earth and Planetary Science Letters, v. 489, pp. 59-71.

Haq, B.U., 2018, Jurassic sea-level variations: a reappraisal. GSA Today, v. 28, pp. 4-10.

Hermoso, M., Le Callonnec, L., Minoletti, F., Renard, M., and Hesselbo, S.P., 2009, Expression of the Early Toarcian negative carbon-isotope excursion in separated carbonate microfractions (Jurassic, Paris Basin). Earth and Planetary Science Letters, v. 277, pp. 194-203.

Hesselbo, S.P., Gröcke, D.R., Jenkyns, H.C., Bjerrum, C.J., Farrimond, P., Morgans Bell, H.S., and Green, O.R., 2000, Massive dissociations of gas hydrate during a Jurassic oceanic anoxic event. Nature, v. 406, pp. 392-395.

Hesselbo, S.P., Jenkyns, H.C., Duarte, L.V., and Oliveira, L.C.V., 2007, Carbon-isotope record of the Early Jurassic (Toarcian) Oceanic Anoxic Event from fossil wood and marine carbonate (Lusitanian Basin, Portugal). Earth and Planetary Science Letters, v. 253, pp. 455-470.

Izumi, K., Miyaji, T., and Tanabe, K., 2012, Early Toarcian (Early Jurassic) oceanic anoxic event recorded in the shelf deposits in the northwestern Panthalassa: evidence from the Nishinakayama formation in the Toyora area, west Japan. Palaeogeography, Palaeoclimatology, Palaeoecology, v. 315-316, pp. 100-108.

Izumi, K., Endo, K., Kemp, D.B., and Inui, M., 2018a, Oceanic redox conditions through the late Pliensbachian to early Toarcian on the northwestern Panthalassa margin: Insights from pyrite and geochemical data. Palaeogeography, Palaeoclimatology, Palaeoecology, v. 493, pp. 1-10.

Izumi, K., Kemp, D.B., Itamiya, S., and Inui, M., 2018b, Sedimentary evidence for enhanced hydrological cycling in response to rapid carbon release during the early Toarcian oceanic anoxic event. Earth and Planetary Science Letters, v. 481, pp. 162-170.

Jenkyns, H.C., 1988, The early Toarcian (Jurassic) anoxic event - stratigraphic, sedimentary, and geochemical evidence. American Journal of Geoscience, v. 288, pp. 101-151.

Jenkyns, H.C., Clayton, C.K., 1997. Lower Jurassic epicontinental carbonates and mudstones from England and Wales: chemostratigraphic signals and the early Toarcian anoxic event. Sedimentology 44, 687706 .

Jenkyns, H.C., 2003, Evidence for a rapid climate change in the MesozoicPaleogene greenhouse world. Philosophical Transactions of the Royal Society, v. 361, pp. 1885-1916.

Jenkyns, H.C., and Clayton, C.J., 1986, Black shales and carbon isotopes in pelagic sediments from the Tethyan Lower Jurassic. Sedimentology, v. 33, pp. 87-106.

Johnson, M.M., Young, M.T., Brusatte, S.L., Thuy, B., and Weis, R., 2019, A catalogue of teleosauroids (Crocodylomorpha: Thalattosuchia) from the Toarcian and Bajocian (Jurassic) of Southern Luxembourg. Historical Biology, v. 31, pp. 1179-1194.

Jozsa, S., Suan, G., and Schlögl, J., 2018, Benthic foraminiferal bioevents in lower to upper Toarcian strata of Southern Beaujolais (SE France). Geobios, v. 51, pp. 137-150.

Kemp, D.B., Coe, A.L., Cohen, A.S., and Schwark, L., 2005, Astronomical pacing of methane release in the Early Jurassic period: Nature, v. 437, pp. 396-399.

Kemp, D.B., Fraser, W.T., and Izumi, K., 2018, Stratigraphic completeness and resolution in an ancient mudrock succession. Sedimentology, v. 65 , pp. $1875-1890$.

Kemp, D.B., Baranyi, V., Izumi, K., and Burgess, R.D., 2019, Organic matter variations and links to climate across the early Toarcian oceanic anoxic event (T-OAE) in Toyora area, southwest Japan). Palaeogeography, Palaeoclimatology, Palaeoecology, v. 530, pp. 90-102.

Konwert, M., and Stumpf, S., 2017, Exceptionally preserved Leptolepidae (Actinopterygii, Teleostei) from the late Early Jurassic Fossil-Lagerstatten of Grimmen and Dobbertin (Mecklenburg-Western Pomerania, Germany). Zootaxa, v. 4243, pp. 249-296.

Korte, C., and Hesselbo, S.P., 2011, Shallow marine carbon and oxygen isotope and elemental records indicate icehouse-greenhouse cycles during the early Jurassic. Paleoceanography, v. 26, PA4219. Doi:10.1029/ 2011PA002160.

Krencker, F.N., Bodin, S., Suan, G., Heimhofer, U., Kabiri, L., and Immenhauser, A., 2015, Toarcian extreme warmth led to tropical cyclone intensification. Earth and Planetary Science Letters, v. 425, pp. 120-130.

Krencker, F.N., Lindström, S., and Bodin, S., 2019, A major sea-level drop briefly precedes the Toarcian oceanic anoxic event: implication for Early Jurassic climate and carbon cycle. Scientific Reports, v. 9, art. 12518. Doi:10.1038/s41598-019-48956-x

Little, C.T.S., and Benton, M.J., 1995, Early Jurassic mass extinction: a global long-term event. Geology, v. 23, pp. 495-498.

Luciani, V., and Cobianchi, M., 1999, The Bonarelli Level and other black shales in the cenomanian turonian of the northeastern Dolomites (Italy): calcareous annofossil and foraminiferal data. Cretaceous Research, v. 20, pp. $135-167$.

Mander, L., and McElwain, J.C., 2019, Toarcian land vegetation loss. Nature Geoscience, v. 12, pp. 405-406.

Martindale, R.C., Them, T.R., Gill, B.C., Marroquin, S.M., and Knoll, A.H., 2017, A new Early Jurassic (ca. $183 \mathrm{Ma}$ ) fossil Lagerstatte from Ya Ha Tinda, Alberta, Canada. Geology, v. 45, pp. 255-258.

Martinez, M., Krencker, F.N., Mattioli, E., and Bodin, S., 2017, Orbital chronology of the Pliensbachian - Toarcian transition from the Central High Atlas Basin (Morocco). Newsletters on Stratigraphy, v. 50, pp. 47-69.

Mattioli, E., Pittet, B., Young, J.R., Bown, P.R., 2004. Biometric analyses of Pliensbachian-Toarcian (Lower Jurassic) coccoliths of the family Biscutaceae: intra- and interspecific variability versus palaeoenvironmental influence. Marine Micropaleontology 52, 5-27.

Mattioli, E., Pittet, B., Petitpierre, L., and Mailliot, S., 2009, Dramatic decrease of the pelagic carbonate production by nannoplankton across the Early Toarcian Anoxic Event (T-OAE). Global and Planetary Changes, v. 65, 134-145.

Maxwell, E.E., and Martindale, R.C., 2017, New Saurorhynchus (Actinopterygii: Saurichthyidae) material from the Early Jurassic of Alberta, Canada. Canadian Journal of Earth Sciences, v. 54, pp. 714-719.

Maxwell, E.E., and Stumpf, S., 2017, Revision of Saurorhynchus (Actinopterygii: Saurichthyidae) from the Early Jurassic of England and Germany. European Journal of Taxonomy, v. 321, pp. 1-29.

McArthur, J.M., 2019, Early Toarcian black shales: A response to an oceanic anoxic event or anoxia in marginal basins? Chemical Geology, v. 
522, pp. 71-83.

McArthur, J.M., Algeo, T.J., van de Schootbrugge, B., Li, Q., and Howarth, R.J., 2008, Basinal restriction, black shales, Re-Os dating, and the Early Toarcian (Jurassic) oceanic anoxic event. Paleoceanography, v. 23, PA4217. Doi:10.1029/2008PA001607

McArthur, J.M., Page, K., Duarte, L.V., Thirwall, M.F., Li, Q., Weis, R., and Comas-Rengifo, M.J., 2019. Sr-isotope stratigraphy $\left({ }^{87} \mathrm{Sr} /{ }^{86} \mathrm{Sr}\right)$ of the lowermost Toarcian of Peniche, Portugal, and its relation to ammonite zonations. Newsletters on Stratigraphy doi:10.1127/nos/2019/0492

McElwain, J.C., Wade-Murphy, J., and Hesselbo, S.P., 2005, Changes in carbon dioxide during an anoxic event linked to intrusion of Gondwana coals. Nature, v. 435, pp. 479-482.

Menegatti, A.P., Weissert, H., Brown, R.S., Tyson, R.V., Farrimond, P., Strasser, A., and Caron, M., 1998. High-resolution $\delta^{13} \mathrm{C}$ stratigraphy through the early Aptian "Livello Selli of the Alpine Tethys. Paleoceanography, v. 13, pp. 530-545.

Menini, A., Mattioli, E., Spangenberg, J.E., Pittet, B., and Suan, G., 2019, New calcareous nannofossil and carbon isotope data for the Pliensbachian/Toarcian boundary (Early Jurassic) in the western Tethys and their paleoenvironmental implications. Newsletters on Stratigraphy, v. 52, pp. 173-196.

Miguez-Salas, O., Rodríguez-Tovar, F.J., and Duarte, L.V., 2017, Selective incidence of the Toarcian oceanic anoxic event on macroinvertebrate marine communities: a case from the Lusitanian basin, Portugal. Lethaia, v. 50, pp. 548-560.

Molina, J.M., and Nieto, L.M., 2019, Facies analysis of the Lower-Middle Toarcian in the External Subbetic (provinces of Murcia and Granada, Southern Spain): palaeoenvironmental conditions. PeerJ Preprints, v. 7, doi:10.7287/peerj.preprints.27957v1

Montero-Serrano, J.C., Föllmi, K.B., Adatte, T., Spangenberg, J.E., Tribovillard, N., Fantasia, A., and Suan, G., 2015, Continental weathering and redox conditions during the early Toarcian Oceanic Anoxic Event in the northwestern Tethys: Insight from the Posidonia Shale section in the Swiss Jura Mountains. Palaeogeography, Palaeoclimatology, Palaeoecology, v. 429, pp. 83-99.

Morten, S.D., and Twichett, R.J., 2009, Fluctuations in the body size of marine invertebrates through the Pliensbachian-Toarcian extinction event. Palaeogeography, Palaeoclimatology, Palaeoecology, v. 284, pp. 29-38.

Muscente, A.D., Martindale, R.C., Schiffbauer, J.D., Creighton, A.L., and Bogan, B.A., 2019. Taphonomy of the Lower Jurassic konservat-lagerstatte at Ya Ha Tinda (Alberta, Canada) and its significance for exceptional fossil preservation during oceanic anoxic events. Palaios, v. 34, pp. 515-541.

Müller, T., Price, G.D., Bajnai, D., Nyerges, A., Kesjár, D., Raucsik, B., Varga, A., Judik, K., Fekete, J., May, Z., and Pálfy, J., 2017, New multiproxy record of the Jenkyns Event (also known as the Toarcian Oceanic Anoxic Event) from the Mecsek Mountains (Hungary): Differences, duration and drivers. Sedimentology, v. 64, pp. 66-86.

Piazza, V., Duarte, L.V., Renaudie, J., and Aberhan, M., 2019, Reduction in body size of benthic macroinvertebrates as a precursor of the early Toarcian (Early Jurassic) extinction event in the Lusitanian Basin, Portugal. Paleobiology, v. 45, pp. 296-316.

Pittet, B., Suan, G., Lenoir, F., Duarte, L.V., and Mattioli, E., 2014, Carbon isotope evidence for sedimentary discontinuities in the lower Toarcian of the Lusitanian Basin (Portugal): sea level changes at the onset of the Oceanic Anoxic Event. Sedimentary Geology, v. 303, pp. 1-14.

Plet, C., Grice, K., Pages, A., Verrall, M., Coolen, M.J.L., Ruebsam, W., Rickard, W.D.A., and Schwark, L., 2017, Palaeobiology of red and white blood cell-like structures, collagen and cholesterol in an ichthyosaur bone. Scientific Reports, v. 7, Art. 13776, doi:10.1038/s41598017-13873-4.

Posenato, R., Bassi, D., Trecalli, A., and Parente, M., 2018, Taphonomy and evolution of Lower Jurassic lithiotid bivalve accumulations in the Apennine Carbonate Platform (southern Italy). Palaeogeography, Palaeoclimatology, Palaeoecology, v. 489, pp. 261-271.
Reolid, M., 2014, Stable isotopes on foraminifera and ostracods for interpreting incidence of the Toarcian Oceanic Anoxic Event in Westernmost Tethys: role of water stagnation and productivity. Palaeogeography, Palaeoclimatology, Palaeoecology, v. 395, pp. 77-91.

Reolid, J., and Reolid, M., 2020, Geochemical compositional mapping of Lower Jurassic trace fossils: Palaeoenvironmental significance and methodological implications. Paleogeography, Palaeoclimatology, Palaeoecology, v. 538, art. 109456, doi:10.1016/j.palaeo.2019.109456.

Reolid, M., Rodríguez-Tovar, F.J., Marok, A., and Sebane, A., 2012, The Toarcian Oceanic Anoxic Event in the Western Saharan Atlas, Algeria (North African Paleomargin): role of anoxia and productivity. Geological Society of America Bulletin, v. 124, pp. 1646-1664.

Reolid, M., Mattioli, E., Nieto, L.M., and Rodríguez-Tovar, F.J., 2014, The Early Toarcian Ocanic Anoxic Event in the External Subbetic (Southiberian Palaeomargin, Westernmost Tethys): geochemistry, nannofossils and ichnology: Palaeogeography, Palaeoclimatology, Palaeoecology, v. 411, pp. 79-94.

Reolid, M., Rivas, P., and Rodríguez-Tovar, F.J., 2015, Toarcian ammonitico rosso facies from the South Iberian Paleomargin (Betic Cordillera, southern Spain): paleoenvironmental reconstruction. Facies, v. 61, art. 22, doi:10.1007/s10347-015-0447-3.

Reolid, M., Molina, J.M., Nieto, L.M., and Rodríguez-Tovar, F.J., 2018, The Toarcian Oceanic Anoxic Event in the South Iberian Palaeomargin. Springer Briefs in Earth Sciences 122 pp.

Reolid, M., Copestake, P., and Johnson, B., 2019a, Foraminiferal assemblages, extinctions and appearances associated with the Early Toarcian Oceanic Anoxic Event in the Llanbedr (Mochras Farm) Borehole, Cardigan Bay Basin, United Kingdom. Paleogeography, Palaeoclimatology, Palaeoecology, v. 532, art. 109277, doi:10.1016/j.palaeo.2019.109277.

Reolid, M., Duarte, L.V., Rita, P., 2019b. Changes in foraminiferal assemblages and environmental conditions during the T-OAE (Early Jurassic) in the northern Lusitanian Basin, Portugal. Paleogeography, Palaeoclimatology, Palaeoecology 520, 30-43.

Reolid, M., Abad, I., and Benito, M.I., 2019c, Upper Pliensbachian-Lower Toarcian methane cold seeps interpreted from geochemical and mineralogical characteristics of Celestine concretions (South Iberian palaeomargin). Palaeogeography, Palaeoclimatology, Palaeoecology, v. 530, pp. 15-31.

Rita, P., Reolid, M., and Duarte, L.V., 2016, Benthic foraminiferal assemblages record major environmental perturbations during the Late Pliensbachian - Early Toarcian interval in the Peniche GSSP, Portugal. Palaeogeography, Palaeoclimatology, Palaeoecology, v. 454, pp. 267-281.

Rita, P., De Baets, K., and Schlott, M., 2018, Rostrum size differences between Toarcian belemnite battlefields. Fossil Record, v. 21, pp. 171182.

Rita, P., Nätscher, P., Duarte, L.V., Weis, R., and De Baets, K., 2019, Mechanisms and drivers of belemnite body-size dynamics across the Pliensbachian-Toarcian crisis. Royal Society Open Science, v. 6, art. 190494, doi:10.1098/rsos.190494.

Rocha, R., Mattioli, E., Duarte, L.V., Pittet, B., Elmi, S., Mouterde, R., Cabral, M.C., Comas-Rengifo, M.J., Gómez, J.J., Goy, A., Hesselbo, S.P., Jenkyns, H.C., Littler, K., Mailliot, S., Luiz, C., Oliveira, L.C., Osete, M.L., Perilli, N., Pinto, S., Ruget, C., and Suan, G., 2016, Base of the Toarcian Stage of the Lower Jurassic defined by the Global Boundary Stratotype Section and Point (GSSP) at the Peniche section (Portugal). Episodes, v. 39, pp. 460-481.

Rodrigues, B., Duarte, L.V., Mendonça Filho, J.G., Santos, L.G. and Oliveira, A.D., 2016, Evidence of terrestrial organic matter deposition across the early Toarcian recorded in the northern Lusitanian Basin, Portugal. International Journal of Coal Geology, v. 168, pp. 35-45.

Rodrigues, B., Silva, R.L., Reolid, M., Mendonça Filho, J.G., and Duarte, L.V., 2019, Sedimentary organic matter and $\delta^{13} C_{\text {kerogen variation on the }}$ southern Iberian palaeomargin (Betic Cordillera, SE Spain) during the latest Pliensbachian-Early Toarcian. Palaeogeography, Palaeocliamtology, 
Palaeoecology, v. 534, art. 109342, doi:10.1016/j.palaeo.2019.109342.

Rodrigues, B., Silva, R.L., Mendonça Filho, J.G., Sadki, D., Mendonça, J.O., and Duarte, L.V., 2020, Late Pliensbachian-Early Toarcian palaeoenvironmental dynamics and the Pliensbachian-Toarcian Event in the Middle Atlas Basin (Morocco). International Journal Coal Geology, v. 217, art. 103339, doi:0.1016/j.coal.2019.103339

Rodríguez-Tovar, F.J., and Uchman, A., 2010, Ichnofabric evidence for the lack of bottom anoxia during the Lower Toarcian Oceanic Anoxic Event (T-OAE) in the Fuente de la Vidriera section, Betic Cordillera, Spain. Palaios, v. 25, pp. 576-587.

Rodríguez-Tovar, F.J., and Reolid, M., 2013, Environmental conditions during the Toarcian Oceanic Anoxic Event (T-OAE) in the westernmost Tethys: influence of the regional contexto $n$ a global phenomenon. Bulletin of Geosciences, v. 66, 697-712.

Rodríguez-Tovar, F.J., Miguez-Salas, O., and Duarte, L.V., 2017, Toarcian Oceanic Anoxic Event induced unusual behaviour and palaeobiological changes in Thalassinoides tracemakers. Palaeogeography, Palaeoclimatology, Palaeoecology, v. 485, pp. 46-56.

Rodríguez-Tovar, F.J., Miguez-Salas, O., Dorador, J., and Duarte, L.V., 2019, Opportunistic behaviour after the Toarcian Oceanic Anoxic Event: The trace fossil Halimedides. Palaeogeography, Palaeoclimatology, Palaeoecology, v. 520, 240-250.

Röhl, H.J., Schmid-Röhl, A., Oschmann, W., Frimmel, A., and Schwark, L., 2001, The Posidonia Shale (Lower Toarcian) of SW Germany: an oxygen-depleted ecosystem controlled by sea-level and palaeoclimate. Palaeogeography, Palaeoclimatology, Palaeoecology, v. 165, pp. 27-52.

Röhl, H.J., and Schmid-Röhl, A., 2005, Lower Toarcian (Upper Liassic) black shales of the central European epicontinental basin: a sequence stratigraphic case study from the SW German Posidonia shale. Society for Sedimentary Geology Special Publication, v. 82, pp. 165-189.

Ros-Franch, S., Echevarría, J., Damborenea, S.E., Manceñido, M.O., Jenkyns, H.C., Al-Suwaidi, A., Hesselbo, S.P., and Riccardi, A.C., 2019, Population response during an Oceanic Anoxic Event: The case of Posidonotis (Bivalvia) from the Lower Jurassic of the Neuquén Basin, Argentina. Palaeogeography, Palaeoclimatology, Palaeoecology, v. 525, pp. 57-67.

Rosales, I., Barnolas, A., Goy, A., Sevillano, A., Armendáriz, M., and López-García, J.M., 2018, Isotope records (C-O-Sr) of late Pliensbachian-early Toarcian environmental perturbations in the westernmost Tethys (Majorca Island, Spain). Palaeogeography, Palaeoclimatology, Palaeoecology, v. 497, pp. 168-185.

Ruebsam, W., Müller, T., Kovacs, J., Palfy, J., and Schwark, L., 2018, Environmental response to the early Toarcian carbon cycle and climate perturbation in the northeastern part of the West Tethys shelf. Gondwana Research, v. 59, pp. 144-158.

Ruebsam, W., Mayer, B., and Schwark, L., 2019, Cryosphere carbon dynamics control early Toarcian global warming and sea level evolution. Global and Planetary Change, v. 172, pp. 440-453.

Ruebsam, W., Reolid, M., and Schwark, L., 2020a, $\delta^{13} \mathrm{C}$ of terrestrial vegetation records Toarcian $\mathrm{CO}_{2}$ and climate gradients. Scientific Reports, v. 10, art. 117, doi:10.1038/s41598-019-56710-6

Ruebsam, W., Reolid, M., Marok, A., and Schwark, L., 2020b, Drivers of benthic extinction during the early Toarcian (Early Jurassic) at the northern Gondwana paleomargin: implications for paleoceanographic conditions. Earth-Science Reviews, v. 203, art. 103117, doi:10.1016/j.earscirev.2020.103117

Saelen, G., Doyle, P., and Talbot, M.R., 1996, Stable-isotope analyses of belemnite rostra from the Whitby Mudstone Fm, England: surface water conditions during deposition of a marine black shale. Palaios, v. 11, pp. 97-117.

Saker-Clark, M., Kemp, D.B., and Coe, A.L., 2019, Portable X-Ray Fluorescence Spectroscopy as a tool for cyclostratigraphy. Geochemistry, Geophysics, Geosystems, v. 20, pp. 2531-2541.

Salazar-Ramírez, R.W., Herrero, C., and Goy A., 2019, Lower Toarcian ammonites and foraminifera assemblages in the San Miguel de Aguayo section (Basque-Cantabrian Basin, Spain). Journal of Iberian Geology, doi:10.1007/s41513-019-00118-8

Schouten, S., van Kaam-Peters, H.M.E., Rijpstra, W.I.C., Schoell, M., and Sinninghe Damst, J.S., 2000, Effects of an oceanic anoxic event on the stable carbon isotopic composition of early Toarcian carbon. American Journal of Science, v. 300, pp. 1-22.

Sell, B., Ovtcharova, M., Guex, J., Bartolini, A., Jourdan, F., Spangenberg, J.E.,, Vicente, J.C., and Schalegger, U., 2014, Evaluating the temporal link between the Karoo LIP and climatic-biologic events of the Toarcian Stage with high-precision U-Pb geochronology. Earth and Planetary Science Letters, v. 15, pp. 48-56.

Silva, R.L., Carlisle, C.A.M., and Wach, G., 2017, A new TOC, rock-eval, and carbon isotope record of Lower Jurassic source rocks from the Slyne Basin, offshore Ireland. Marine and Petroleum Geology, v. 86, pp. 499-511.

Slater, S.M., Twitchett, R., Danise, S., and Vajda, V., 2019, Substantial vegetation response to Early Jurassic global warming with impacts on oceanic anoxia. Nature Geoscience, v. 12, pp. 462-467.

Soulimane, C., Reolid, M., and Marok, A., 2017a, Ostracod assemblages from the uppermost Pliensbachian and Lower Toarcian of the Traras Mountains (Tlemcen Domain, north Algeria). Arabian Journal of Geosciences 10, art. 393, doi:10.1007/s12517-017-3180-0

Soulimane, C., Reolid, M., Rita, P., Marok, A., and Duarte, L.V., 2017b, Uppermost Pliensbachian-lowermost Toarcian ostracod assemblages from the Western Tethys: Comparison between Traras Mountains (Algeria), Subbetic (Spain), and Algarve (Portugal). Annales de Paleontologie, v. 4, pp. 251-269.

Soulimane, C., Marok, A., and Reolid, M., 2020, Similarity analysis of ostracoda faunas in the Western Tethys during the Late PliensbachianEarly Toarcian (Early Jurassic). Arabian Journal of Geosciences, v. 13, art. 136, doi:10.1007/s12517-020-5178-2.

Storm, M.S., Hesselbo, S.P., Jenkyns, H.C., Ruhl, M., Ullmann, C.V., Xu, W., Leng, M., Riding, J., and Gorbanenko, O., 2020. Orbital pacing and secular evolution of the Early Jurassic carbon cycle. Proceedings of the National Academy of Sciences of the United States of America, doi:10.1073/pnas.1912094117.

Stumpf, S., and Kriwet, J., 2019, A new Pliensbachian elasmobranch (Vertebrata, Chondrichthyes) assemblage from Europe, and its contribution to the understanding of the late Early Jurassic elasmobranch diversity and distributional patterns. Paläontologische Zeitschrift, v. 93, pp. 637-658.

Suan, G., Mattioli, E., Pittet, B., Lécuyer, C., Suchéras-Marx, B., Duarte, L.V., Philippe, M., Reggiani, L., and Martineau, F., 2010, Secular environmental precursors to Early Toarcian (Jurassic) extreme climate changes. Earth and Planetary Science Letters, v. 290, pp. 448-458.

Suan, G., Nikitenko, B.L., Rogov, M.A., Baudin, F., Spangenberg, J.E., Knyazev, V.G., Glinskikh, L.A., Goryacheva, A.A., Adatte, T., Riding, J.B., Föllmi, K.B., Pittet, B., Mattioli, E., and Lécuyer, C., 2011, Polar record of Early Jurassic massive carbon injection. Earth and Planetary Science Letters, v. 312, pp. 102-113.

Suan, G., Schöllhorn, I., Schlögl, J., Segit, T., Mattioli, E., Lécuyer, C., and Fourel, F., 2018, Euxinic conditions and high sulfur burial near the European shelf margin (Pieniny Klippen Belt, Slovakia) during the Toarcian oceanic anoxic event. Global and Planetary Change, v. 170, pp. 246-259.

Them, T.R., Gill, B.C., Caruthers, A.H., Grocke, D.R., Tulsky, E.T., Martindale, R.C., Poulton, T.P., and Smith, P.L., 2017b, High-resolution carbon isotope records of the Toarcian Oceanic Anoxic Event (Early Jurassic) from North America and implications for the global drivers of the Toarcian carbon cycle. Earth and Planetary Science Letters, v. 459, pp. 118-126.

Them, T.R., Gill, B.C., Selby, D., Grocke, D.R., Friedman, R.M., and Owens, J.D., 2017a, Evidence for rapid weathering response to climatic warming during the Toarcian Oceanic Anoxic Event. Scientific Reports, v. 7, art. 5003, Doi:10.1038/s41598-017-05307-y

Them, T.R., Gill, B.C., Carutherns, A.H., Gerhardt, A.M., Grocke, D.R., Lyons, T.W., Marroquin, S.M., Nielsen, S.G., Alexandre, J.P.T., and 
Owens, J.D., 2018, Thallium isotopes reveal protracted anoxia during the Toarcian (Early Jurassic) associated with volcanism, carbon burial, and mass extinction. Proceedings National Academy Sciences United States America, v. 115, pp. 6596-6601.

Them, T.R., Jagoe, C.H., Caruthers, A.H., Gill, B.C., Grasby, S.E., Grocke, D.R., Yin, R., and Owens, J.D., 2019, Terrestrial sources as the primary delivery mechanism of mercury to the oceans across the Toarcian Oceanic Anoxic Event (Early Jurassic). Earth and Planetary Science Letters, v. 507, pp. 62-72.

Thibault, N., Ruhl, M., Ullmann, C.V., Korte, C., Kemp, D.B., Grocke, D.R., and Hesselbo, S.P., 2018, The wider context of the Lower Jurassic Toarcian oceanic anoxic event in Yorkshire coastal outcrops, UK. Proceedings of the Geologists Association, v. 129, pp. 372-391.

Trecalli, A., Spangenberg, J., Adatte, T., Föllmi, K.B., and Parente, M., 2012. Carbonate platform evidence of ocean acidification at the onset of the early Toarcian oceanic anoxic event. Earth and Planetary Science Letters, v. 357, pp. 214-225.

Val, J., Badenas, B., Aurell, M., and Rosales, I., 2017, Cyclostratigraphy and chemostratigraphy of a bioclastic storm-dominated carbonate ramp (late Pliensbachian, Iberian Basin). Sedimentary Geology, v. 355, pp. 93-113.

Vincent, P., Allemand, R., Taylor, P.D., Suan, G., and Maxwell, E.E., 2017, New insights on the systematics, palaeoecology and palaeobiology of a plesiosaurian with soft tissue preservation from the Toarcian of Holzmaden, Germany. Science of Nature, v. 104, pp. 5-6.

Wignall, P.B., Newton, R.J., and Little, C.T.S., 2005, The timing of paleoenvironmental change and cause-and-effect relationships during the Early Jurassic mass extinction in Europe. American Journal of Science, v. 305, pp. 1014-1032.

Xu, W., Ruhl, M., Jenkyns, H.C., Hesselbo, S.P., Riding, J.B., Selby, D., Naafs, D.A., Weijers, J.W., Pancost, R.D., Tegelaar, E.W., and Idiz, E.F., 2017, Carbon sequestration in an expanded lake system during the Toarcian oceanic anoxic event. Nature Geoscience, v. 10, pp. 129-134.

Xu, W., MacNiocaill, C., Ruhl, M., Jenkyns, H., Riding, J.B., and Hesselbo, H.P., 2018a, Magnetostratigraphy of the Toarcian Stage (Lower Jurassic) of the Llanbedr (Mochras Farm) Borehole, Wales: basis for a global standard and implications for volcanic forcing of palaeoenvironmental change. Journal of the Geological Society, v. 175, pp. 594-604.

Xu, W., Ruhl, M., Jenkyns, H.C., Leng, M.J., Huggett, J.M., Minisini, D., Ullmann, C.V., Riding, J.B., Weijers, J.W.H., Storm, M.S., Percival, L.M.E., Tosca, N.J., Idiz, E.F., Tegelaar, E.W., and Hesselbo, H.P., 2018b, Evolution of the Toarcian (Early Jurassic) carbon cycle and global climatic controls on local sedimentary processes (Cardigan Bay Basin, UK). Earth and Planetary Science Letters, v. 484, pp. 396-411.

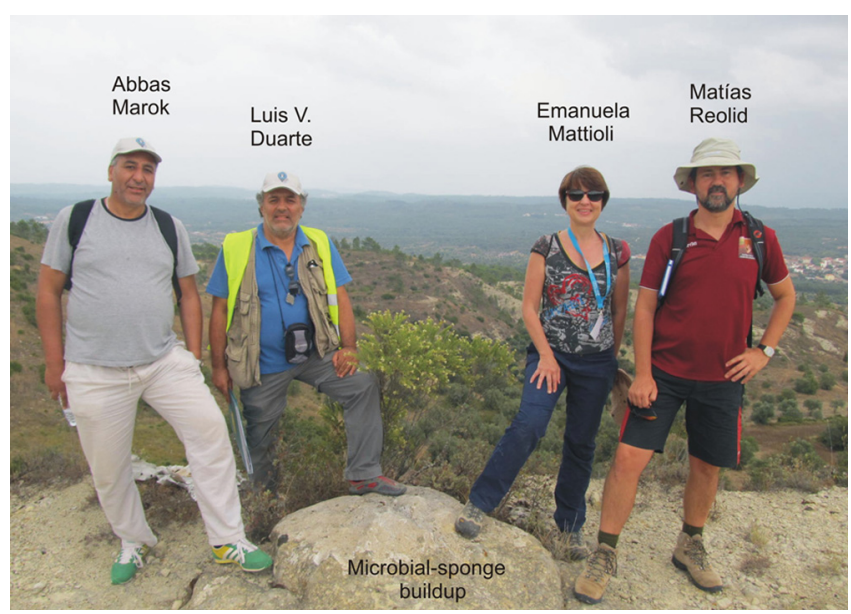

Matías Reolid has a wide experience in the study of the T-OAE from Traras Mountains and Saharan Atlas (Algeria), Middle Atlas (Morocco), Lusitanian Basin (Portugal), Betic Cordillera (Spain), Umbria Marche (Italy) and North Siberia (Russia). His research has been focused on the ecostratigraphic analysis of foraminiferal assemblages and trace fossils, the use of geochemical proxies for redox and palaeoproductivity conditions and isotopic geochemistry to approach the environmental conditions previous, during and after the biotic crisis (T-OAE, OAE2 and PETM).

Emanuela Mattioli is one of the most experimented researcher on the study of the T-OAE from outcrops of North Africa, Portugal, Spain, France, Italy, Germany, Greece, North Siberia, Tibet... Her work has been focused on the analysis of fossil calcareous nannoplankton among other topics, for interpreting carbon cycle perturbation and carbonate productivity of pelagic carbonate during this event. She uses the fossil calcareous nannoplankton as a tool for learning the trophic conditions and the palaeotemperature of ocean surface waters, and interpreting palaeoceanography. She worked on the proposal of the GSSP for Toarcian Stage in the Peniche section (Portugal).

Luis $\boldsymbol{V}$. Duarte (University of Coimbra, Portugal) has worked on integrated stratigraphy analysis, sedimentology and geochemistry of marine carbonate and organic deposits, with special emphasis in the Lower Jurassic series of Portugal. Has been involved in multiple national and bilateral projects concerning the T-OAE and participated in the proposal of the GSSP for the Toarcian Stage in the Peniche section (Portugal). In addition to all the scientific research, it develops a remarkable activity of scientific dissemination among different audiences.

Abbas Marok (University of Tlemcen, Algeria) works on sedimentology, cartography of anoxic levels of Jurassic and Cretaceous, and petroleum geology. He has studied actively on macroinvertebrate assemblages (mainly ammonites and brachiopods) of Pliensbachian-Toarcian with biostratigraphic interest for the correlation with other areas of North Africa. Moreover, part of his research is focused on the incidence of T-OAE and OAE2 on the foraminiferal and ostracod assemblages. 